Research

\title{
Bob-I is expressed in classic Hodgkin lymphoma
} Howayda S Abd El All*

\author{
Address: Department of Pathology, Faculty of Medicine, Suez Canal University, Ismailia, Egypt \\ Email: Howayda S Abd El All* - howayda@link.net \\ * Corresponding author
}

Published: 8 March 2007

Diagnostic Pathology 2007, 2:10 doi:10.1 186/1746-1596-2-10

This article is available from: http://www.diagnosticpathology.org/content/2/1/10

(c) 2007 Abd El All; licensee BioMed Central Ltd.

This is an Open Access article distributed under the terms of the Creative Commons Attribution License (http://creativecommons.org/licenses/by/2.0), which permits unrestricted use, distribution, and reproduction in any medium, provided the original work is properly cited.
Received: 7 February 2007

Accepted: 8 March 2007

\begin{abstract}
Background: Almost all researchers agree on the lack of Bob-I expression in Hodgkin/ReedSternberg (H/RS) cells in classic Hodgkin lymphoma (CHL), and utilize this marker as a diagnostic tool in conjunction with other markers to differentiate between lymphocyte predominance Hodgkin lymphoma (LPHL) and CHL.

Aim: To study the immunohistochemical (IHC) expression of Bob-I in Egyptian CHL and to correlate this expression with Epstein-Barr virus (EBV) viral load.

Materials and methods: Paraffin sections of randomly selected $18 \mathrm{CHL}$ cases were included: 2 lymphocyte rich (LR), 4 mixed cellularity (MC), 10 nodular sclerosis (NS) and 2 lymphocyte depletion (LD). All cases were immunostained for Bob-I. EBV was evaluated by EBV early RNA transcripts in situ hybridization (EBER ISH) and immunostaining for EBV latent membrane proteinI (LMP-I).

Results: Sixty seven percent of cases (12/18) were positive for EBV by ISH and/or immunostaining for LMP-I. Moderate to strong nuclear Bob-I was observed in $94 \%$ of cases. The positivity ranged between $25-100 \%$. Bob-I immunoreactivity was strongly associated with EBV positivity $(\mathrm{p}<0.00 \mathrm{I})$.

Conclusion: This study proves nuclear IHC expression of Bob-I on H/RS in CHL implying the difficulties in applying this marker to differentiate between LPHL and CHL. Does this difference between Western and Egyptian CHL reflect genetic and/or environmental factors, or simply no difference exists as most researchers are concentrated on the Western population and no comparative studies have been done. Studies from other countries might answer this question.
\end{abstract}

\section{Background}

According to the World Health Organization (WHO) classification of haematological malignancies [1], the B-cell specific transcriptional co-activator or Bob-1/OCA-B is not expressed on $\mathrm{H} / \mathrm{RS}$ cells, a point used to differentiate between CHL and LPHL, the latter being Bob-1 positive. Bob-1/OCA-B located on chromosome 11q23.1 [2], is involved in the transcription of immunoglobulin (Ig) genes through recruitment of the highly conserved octamer site of Ig promoters, mediated by either Oct-1 or Oct-2 transcription factor [3]. Bob-1 is essential for the response of $\mathrm{B}$ cells to antigens, and is required for the formation of the germinal centre (GC) [4].

EBV, the main etiologic agent for HL [5], has been reported in 30-50\% of cases in developed countries and in up to $95 \%$ of cases in developing ones [6]. The detection of EBV in H/RS cells is mainly based on the detection 
of the latently expressed gene LMP-1 or on the detection of EBV early RNA transcripts (EBER) [7].

As H/RS cells originate from the GC [8-10], they are expected to express B cell markers such as Bob-1. Therefore this work was undertaken to study the expression of Bob-1 in Egyptian CHL and to correlate this expression with EBV viral load in an attempt to find out if differences do exist between Western and Egyptian CHL, for optimal assessment of the treatment regime.

\section{Materials and methods}

\section{Classic Hodgkin lymphoma cases}

Paraffin sections of randomly selected CHL were classified according to the WHO [1]. A total of $18 \mathrm{CHL}$ cases were studied. These included 2 cases of LRHL, 4 MCHL, 10 NSHL, 2 LDHL. The positive controls consisted of 2 reactive nodes selected with follicular hyperplasia and 2 cases of LPHL. The initial diagnostic panel included CD30, CD15, CD20 and CD3. EMA and ALK-1 were performed whenever indicated to rule out LPHL and anaplastic large cell lymphoma.

\section{Immunohistochemistry}

The expression of Bob-1 and EBV LMP-1 was evaluated by immunostaining (table 1). Following deparaffinization, endogenous peroxidase was inhibited by tissue sections incubation for 10 minutes at room temperature in $0.3 \%$ $\mathrm{H} 2 \mathrm{O} 2$. Following antigen retrieval, slides were rinsed in distilled water and finally phosphate buffered saline (PBS). All incubations were performed at room temperature. After incubation with the primary antibody, sections were rinsed in PBS and incubated with the LSAB-2 detection kit and the steps were followed according to the manufacturer instructions (Dakocytomation). Diaminobenzedine tetrachloride (DAB) was applied for 10 minutes and lastly, sections were counterstained with Harris haematoxylin (Hx).

\section{Evaluation of immunohistochemical staining}

The percentage of positively stained H/RS cells were semiquantitatively determined as follows: 0 - absence or staining of less than $5 \%$ of $\mathrm{H} / \mathrm{RS}$ cells; +) $5-25 \%$; +) $>25-$ $50 \% ;+++)>50-75 \% ;++++)>75 \%$ of H/RS cells showed a positive staining. In all cases, small reactive lymphocytes served as positive internal control for Bob-1, in addition to the positivity of the reactive nodes and lymphocytic/ histiocytic cells of LPHL.

\section{In-situ hybridization}

The ISH steps were performed according to the manufacturer's instructions (Novocastra, NCL-EBV-K). The slides were first dewaxed in xylene, hydrated in descending grades of alcohol and lastly immersed in water. One hundred $\mu$ l of proteinase $\mathrm{K}$ in $0.05 \mathrm{mM}$ Tris/HCL buffer $\mathrm{pH}$ 7.6 were applied for 10 minutes at $37^{\circ} \mathrm{C}$. This step was followed by slides immersion in water, dehydration and air drying. Depending on the tissue section, 20 to $50 \mu \mathrm{l}$ of the probe hybridization solution were applied. Sections were coverslipped and incubated for 2 hours at $37^{\circ} \mathrm{C}$. The covers were allowed to drain off into a beaker; they were then washed in Tris containing $0.1 \%$ triton $\mathrm{X}-100$. For the detection, $100 \mu \mathrm{l}$ of the blocking solution was applied for 10 minutes followed by rabbit $\mathrm{F}(\mathrm{ab}$ ') anti-FTTC conjugated to alkaline phosphatase (AP) diluted 1:100 for 30 minutes. Slides were subsequently washed in TBS followed by the AP substrate buffer. The AP activity was demonstrated by incubation in dark overnight with a mixture solution of 5 bromo-4 choro indolyl phosphate, nitroblue tretrazolium (BCNT). Finally, the slides were washed and counterstained with Mayer's haematoxylin. The control of the procedure included positive control sections and negative control probe supplied with the ISH kit.

\section{Evaluation of in-situ hybridisation}

The staining was considered positive when dark blue to black dots were encountered in the nuclei of the H/RS cells together with positivity of the positive control tissue and negativity of the duplicate sections hybridized with the negative probe.

\section{Statistical analysis}

The association between Bob-1 positive cells and EBV viral load was evaluated using the Chi square test.

\section{Results}

In reactive nodes, residual follicles and inflammatory milieu of HL, strong nuclear Bob-1 was expressed in GC B

Table I: Reagents used for IHC in the study

\begin{tabular}{lcc}
\hline & Bob-I & LMP-I \\
\hline Source & Santa Cruz & Dakocytomation \\
Reference & Sc 955 rabbit polyclonal & Citrate pH $6.0,750 \mathrm{w} \times 5 \mathrm{~m} \times 3$ times \\
Heat induced epitope retrieval & & $1: 50$ \\
Dilution & $1: 1500$ & $30 \mathrm{~m}$ \\
Incubation & $60 \mathrm{~m}$ & Membranous, cytoplasmic and/or paranuclear dot \\
Interpretation & Nuclear & \\
\hline
\end{tabular}


cells while moderate staining was seen in scattered mantle zone B cells and interfollicular T cells.

In $\mathrm{CHL}$, moderate to strong nuclear IHC Bob-1+ H/RS cells were encountered in $94 \%$ of cases irrespective of the subtype. The percentage of positive cells ranged from 25$100 \%$ (table 2, figures 1, 2, 3). Membranous, cytoplasmic and/or paranuclear dot staining for LMP-1 (figure 4) was identified in $61 \%$, while nuclear staining for EBER-ISH (figure 5) was encountered in $67 \%$ of cases. A close association was found between Bob-1 immunoreactivity and EBV viral load $(\mathrm{p}<0.001)$.

\section{Discussion}

CHD is a B-cell neoplasm in nearly all instances derived from the GC B cells harbouring somatically mutated $\mathrm{IgV}$ region genes. However, these cells have consistently lost their Ig gene transcription ability, due to functional defects in the Ig gene regulatory elements [10-12]. The defect has been attributed to crippling mutations $[11,12]$, a defect in the transcription machinery due to lack of expression of the octamer transcription factor Oct2 and/ or its coactivator Bob-1 $[12,14]$, or epigenetic silencing in the inhibition of IgH transcription [15].

The expression of Bob-1 in H/RS cells was a surprising finding. To our knowledge, this is the first study reporting strong nuclear Bob-1 in almost all H/RS cells. In reactive nodes and non neoplastic cells in HL, Bob-1 IHC expression is concordant with the literature $[16,17]$. However, in neoplastic conditions, Bob-1 positivity is restricted to LPHL and has been a useful tool in differentiating it from CHL $[13,18-20]$. Only one previous study using tissue microarray, reported Bob-1+ H/RS cells in $17 \%$ of cases with strong Bob-1 positivity in only $2 \%$ of cases [21].

Should the strong IHC expression of Bob- 1 in H/RS cells is really to be an unexpected finding? First, in HL cell lines, Oct-2 has been reported in one study to be constantly expressed on H/RS cells [22]. Second, a close resemblance has been found between primary mediastinal B-cell lymphoma (PMBL) and CHL [23-25]. PMBL signature genes

Table 2: Bob-I and EBV expressions in CHL

\begin{tabular}{lccc}
\hline CHL Subtype & Bob-I & \multicolumn{2}{c}{ EBV viral load } \\
\cline { 3 - 4 } & & EBER & LMP-I \\
\hline LRHL & $2 / 2$ & $2 / 2$ & $1 / 2$ \\
MC & $4 / 4$ & $3 / 4$ & $3 / 4$ \\
NS & $9 / 10$ & $6 / 10$ & $6 / 10$ \\
LD & $2 / 2$ & $1 / 2$ & $1 / 2$ \\
Total & $17 / 18$ & $12 / 18$ & $11 / 18$ \\
$\%$ & $94 \%$ & $67 \%$ & $61 \%$
\end{tabular}

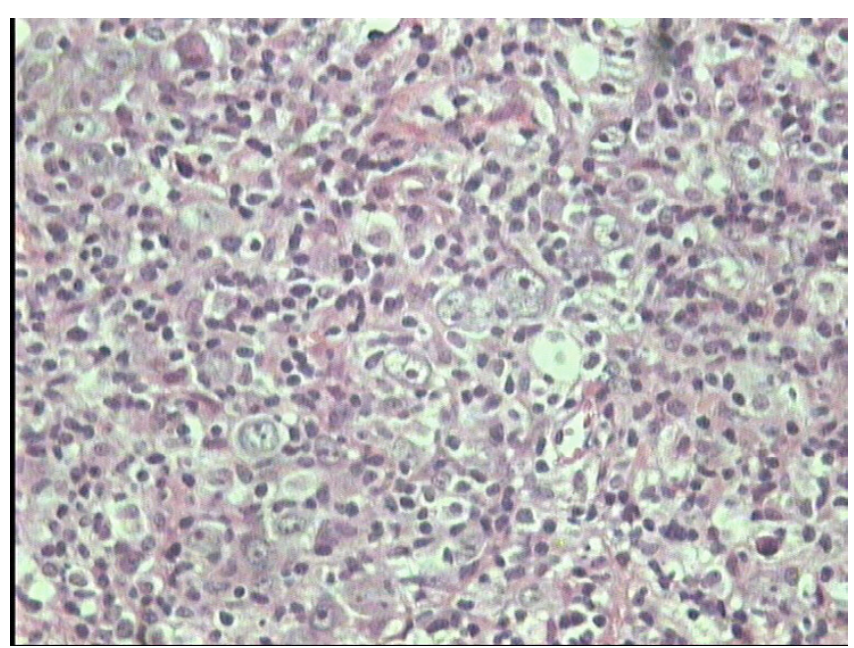

Figure I

MCHL H/RS cells in an inflammatory background, H\&E $\times 40$.

revealed an extraordinarily robust gene expression relationship between PMBL and HL, strongly supporting a pathogenetic relationship between these two lymphoma types $[24,25]$. On IHC basis, PMBL are PAX5/BSAP+, Bob1+, Oct-2+, PU.1+, Bcl-2+, CD30+, HLA-DR+, Bcl-6+/-, Mum-1+/- [26], markers already identified on CHL with the exception of PU.1, Bob-1 and Oct-2 [13,19,28,27]. In addition, the MAL protein initially a PMBL marker [29], has been identified on H/RS cells from a case of NSHL in the study of Rosenwald et al [24]. Furthermore, PMBL and HL have rearranged Ig genes but lack surface $\operatorname{Ig}[10,11,24]$. Considering these previous findings together with the results of our research, one can conclude that the expres-

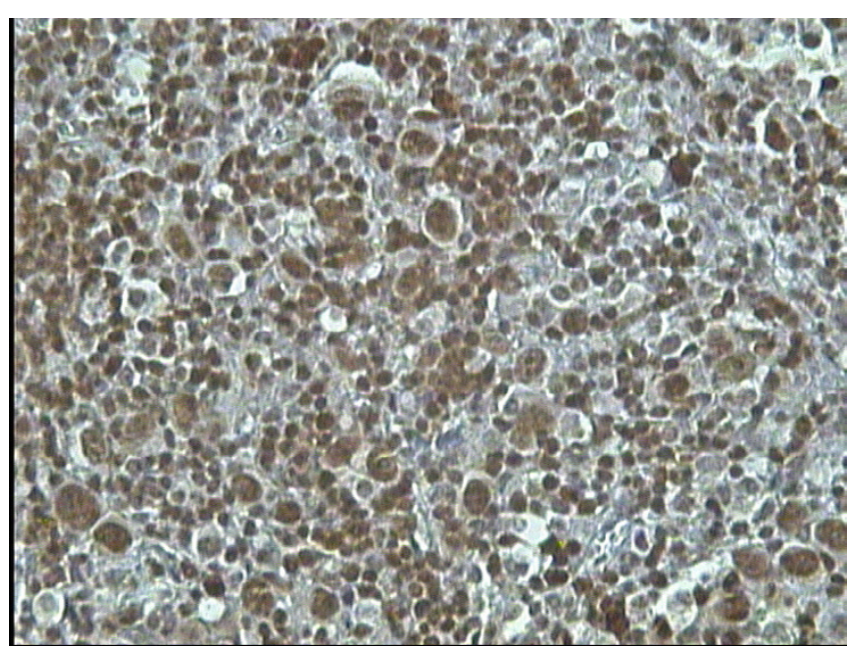

\section{Figure 2}

MCHL: strong nuclear Bob-I staining in all $\mathrm{H} / \mathrm{RS}$ cells, Bob-I immunostaining, DAB, $\mathrm{Hx}, \times 40$. 


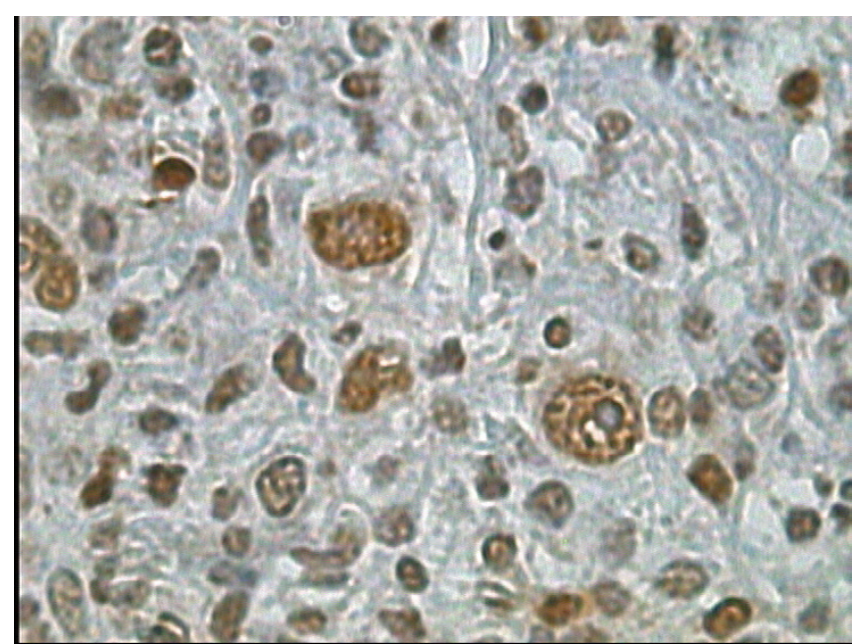

\section{Figure 3}

MCHL: higher power magnification of the previous figure, Bob-I immunostaining, DAB, $\mathrm{Hx}, \times 100$.

sion of Bob-1 in the Egyptian population is not an uncommon finding.

What could be the other explanations of Bob-1+H/RS cells in the present study? It has been speculated that EBV contributes to the transformation and maintenance of H/RS cells, by rescuing them from apoptosis. This has been attributed to the oncogenic potential of LMP-1 on B cells through upregulation of anti-apoptosis genes including bcl-2 [30], downregulation of p16INK4a [31] and activation of NFKB [32]. What is the relation between EBV and Bob-1? NFKB and Bob-1 are transcription factors required for mouse B cell differentiation, serum IgM production,

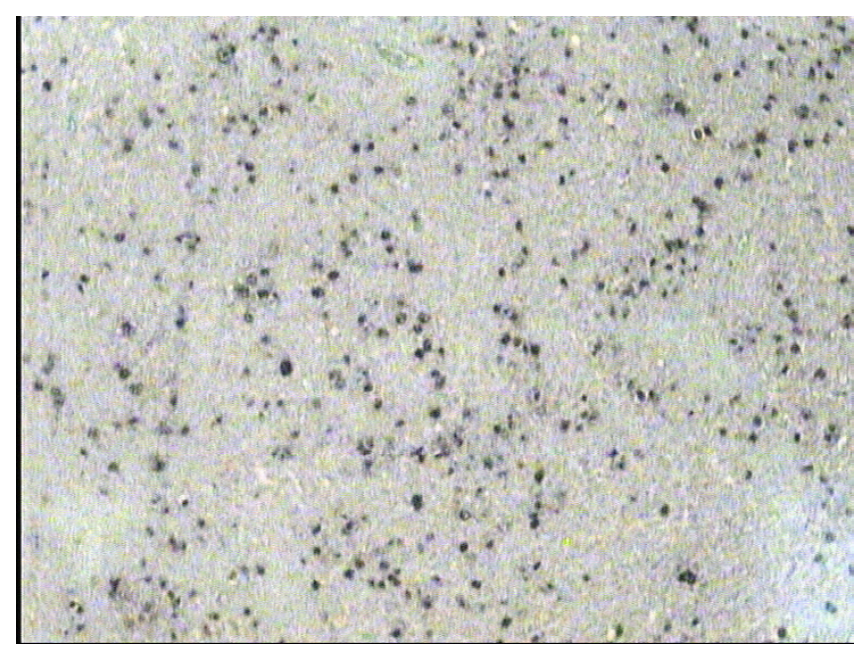

Figure 4

MCHL: strong nuclear EBV staining, EBER-ISH, BNCT, $\mathrm{Hx}$, × 20.

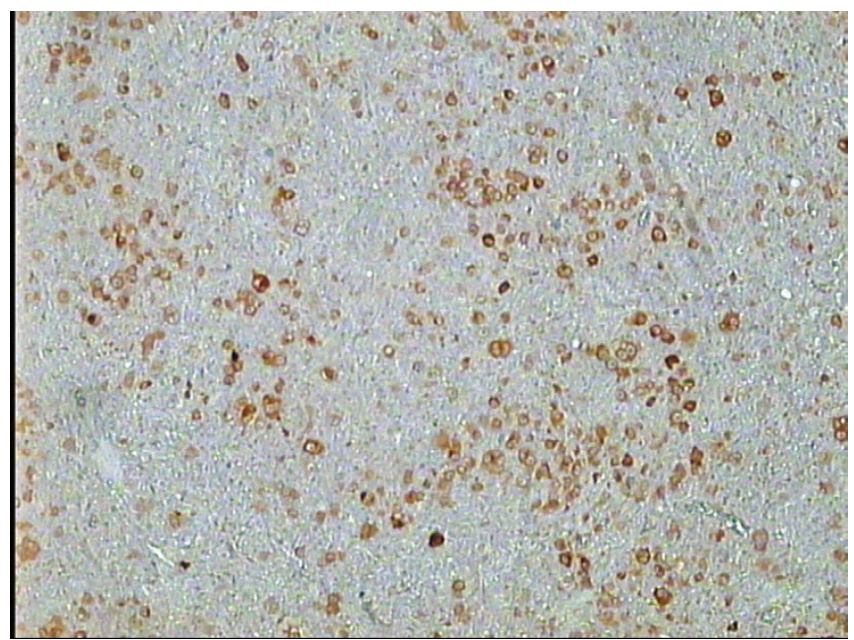

Figure 5

MCHL: LMP-I immunostaining of the same case, DAB, Hx, $\times$ 20.

late B cell maturation and function [33]. It seems that the activation of NFKB in EBV positive cases is associated with up regulation of Bob-1 since there is a close association between the expression of Bob-1 and EBV in the present study.

In conclusion, this study confirms the nuclear expression of Bob-1 on H/RS cells in CHL, making the utility of Bob1 to differentiate between LPHL and CHL difficult. These points open questions concerning environmental factors especially early EBV infection in developing countries and to lesser extent genetic ones. Is there truly a difference between Western and Egyptian CHL, or no differences actually exist as most researchers are more concentrated on their own Western-based populations? We feel that our work necessitates cooperative studies between different countries to answer these questions.

\section{Abbreviations}

H/RS: Hodgkin/Reed-Sternberg, CHL: classic Hodgkin lymphoma, LPHL: lymphocyte predominance Hodgkin lymphoma, LR: lymphocyte rich, MC: mixed cellularity, NS: nodular sclerosis, LD: lymphocyte depletion, EBV: Epstein-Barr virus, EBER ISH: EBV in situ hybridization, LMP-1: EBV latent membrane protein-1

\section{Competing interests}

The author(s) declare that they have no competing interests.

\section{Acknowledgements}

Study effectuated in the Diagnostic Oncology Unit, Faculty of Medicine, Suez Canal University. The technical support of Mohamed El Laboudy, Mohamed El Cherbeiny and Nahla Abd El Reheem is appreciated. The 
author expresses her extreme gratitude to Medico-Pharma trade, the distributor of Novocastra in Egypt for providing EBER in situ hybridization.

\section{References}

I. Jaffe ES, Harris NL, Vardiman JW: Pathology and Genetics. Tumors of hematopoeitic and lymphoid tissues. WHO Classification of Tumors $200 \mathrm{I}$.

2. Galieque Zouitina S, Quief S, Hildebrand MP, Denis C, Lecocq G, Collyn-d'Hooghe M, Bastard C, Yuille M, Dyer MJ, Kerckaert JP: The B cell transcriptional coactivator $B O B I / O B F$ I gene fuses to the LAZ3/BCL6 gene by $t(3 ; I I)(q 27 ; q 23.1)$ chromosomal translocation in a B cell leukemia line (Karpas 23I). Leukemia 1996, 10:579-587.

3. Strubin M, Newell JW, Matthias P: OBF-I, a novel B cell-specific coactivator that stimulates immunoglobulin promoter activity through association with octamer-binding proteins. Cell 1995, 80:497-506.

4. Schubart DB, Rolink A, Kosco-Vilbois MH, Botteri F, Matthias P: Bcell-specific coactivator OBF-I/OCA-B/Bobl required for immune response and germinal centre formation. Nature 1996, 383:538-542.

5. Herbst H, Niedobitek G, Kneba M, Hummel M, Finn T, Anagnostopoulos I, Bergholz M, Krieger G, Stein H: High incidence of EpsteinBarr virus genomes in Hodgkin's disease. Am J Pathol 1990 , 137:13-18.

6. Glaser SL, Lin RJ, Stewart SL, Ambinder RF, Jarrett RF, Brousset $P$, Pallesen G, Gulley ML, Khan G, O'Grady J, Hummel M, Preciado MV Knecht H, Chan JK, Claviez A: Epstein-Barr virus-associated Hodgkin's disease: Epidemiologic characteristics in international data. Inter J Cancer I997, 70:375-382.

7. Lauritzen AF, Hording U, Nielsen HW: Epstein-Barr virus, and Hodgkin's disease: a comparative immunological, in situ hybridization, and polymerase chain reaction study. APMIS 1994, 102:495-500.

8. Cossman J, Annunziata CM, Barash S, Staudt L, Dillon P, He WW, Ricciardi-Castagnoli P, Rosen CA, Carter KC: Reed-Sternberg cell genome expression supports a B cell lineage. Blood 1999, 94:4II-4I6.

9. Foss HD, Reusch R, Demel G, Lenz G, Anagnostopoulos I, Hummel M, Stein $H$ : Frequent expression of the B cell-specific activator protein in Reed-Sternberg cells of classical Hodgkin's disease provides further evidence for its B cell origin. Blood 1999 94:3108-3113

10. Marafioti T, Hummel M, Foss HD, Laumen H, Korbjuhn P, Anagnostopoulos I, Lammert H, Demel G, Theil J, Wirth T, Stein H: Hodgkin and Reed-Sternberg cells represent an expansion of a single clone originating from a germinal center $B$ cell with functional immunoglobulin gene rearrangements but defective immunoglobulin transcription. Blood 2000, 95: | 443-1450.

II. Küppers R, Rajewsky K, Zhao M, Simons G, Laumann R, Fischer R, Hansmann M: Hodgkin Disease: Hodgkin and Reed-Sternberg cells picked from histological sections show clonal immunoglobulin gene rearrangements and appear to be derived from B cells at various stages of development. PNAS 1994, 91:10962-10966.

12. Kanzler H, Küppers R, Hansmann ML, Rajewsky K: Hodgkin and Reed-Sternberg cells in Hodgkin's disease represent the outgrowth of a dominant tumor clone derived from (crippled) germinal center B cells. J Exp Med 1996, I 84: |495-I505.

13. Stein H, Marafioti T, Foss HD, Laumen H, Hummel M, Anagnostopoulos I, Wirth T, Demel G, Falini B: Down-regulation of BOB.I OBF.I and Oct2 in classical Hodgkin disease but not in lymphocyte predominant Hodgkin disease correlates with immunoglobulin transcription. Blood 2001, 97:496-50I.

14. Hertel CB, Zhou XG, Hamilton-Dutoit SJ, Junker S: Loss of B cell identity correlates with loss of $B$ cell-specific transcription factors in Hodgkin/Reed-Sternberg cells of classical Hodgkin lymphoma. Oncogene 2002, 2 I:4908-4920.

15. Ushmorov A Ritz O, Hummel M Leithauser F, Moller P, Stein H, Wirth T: Epigenetic silencing of the immunoglobulin heavychain gene in classical Hodgkin lymphoma-derived cell lines contributes to the loss of immunoglobulin expression. Blood 2004, 104:3326-3334.

16. Greiner A, Mülle KB, Hess J, Pfeffer K, Müller-Hermelink HK, Wirth $\mathrm{T}$ : Up-Regulation of BOB. I/OBF. I Expression in Normal Germinal Center B Cells and Germinal Center-Derived Lymphomas. Am J Pathol 2000, I 56:501-507.

17. Zwilling S, Dieckmann A, Pfisterer P, Angel P, Wirth T: Inducible expression and phosphorylation of coactivator BOB.I/OBF.I in T cells. Science 1997, 277:221-225.
18. Re D, Müschen M, Ahmadi T, Wickenhauser C, Staratschek-Jox A, Holtick U, Diehl V, Wolf J: Oct-2 and Bob-I Deficiency in Hodgkin and Reed Sternberg Cells. Cancer Res 200I, 6 I:2080-2084.

19. Browne P, Petrosyan K, Hernandez A, Chan JA: The B-Cell transcription factors BSAP, Oct-2, and BOB. I and the Pan-B-cell markers CD20, CD22, and CD79a are useful in the differential diagnosis of classic Hodgkin Lymphoma. Am J Clin Pathol 2003, I 20:767-777.

20. Loddenkemper C. Anagnostopoulos I, Hummel M, Johrens-Leder K, Foss HD, Jundt F, Wirth T, Dorken B, Stein H: Differential Emu enhancer activity and expression of BOB.I/OBF.I, Oct2, PU.I, and immunoglobulin in reactive B-cell populations, $B$ cell non-Hodgkin lymphomas, and Hodgkin lymphomas. Pathol 2004, 202:60-69.

21. García-Cosío M, Santón A, Martín P, Camarasa N, Montalbán C García JF, Bellas C: Analysis of transcription factor OCT.I, OCT.2 and BOB.I expression using tissue arrays in classical Hodgkin's lymphoma. Mod Pathol 2004, I 7: I 53 I- I 538.

22. Bargou RC, Leng C, Krappmann D, Emmerich F, Mapara MY, Bommert K, Royer HD, Scheidereit C, Dorken B: High-level nuclear NF. kappa $B$ and Oct-2 is a common feature of cultured Hodgkin/ Reed-Sternberg cells. Blood 1996, 87:4340-4347

23. Joos S, Kupper M, Ohl S, von Bonin F, Mechtersheimer G, Bentz M, Marynen P, Moller P, Pfreundschuh M, Trumper L, Lichter P: Genomic imbalances including amplification of the tyrosine kinase gene JAK2 in CD30+ Hodgkin cells. Cancer Res 2000 60:549-552

24. Rosenwald A, Wright G, Leroy K, Yu X, Gaulard P, Gascoyne RD, Chan WC, Zhao T, Haioun C, Greiner TC, Weisenburger DD, Lynch JC, Vose J, Armitage JO, Smeland EB, Kvaloy S, Holte H, Delabie J, Campo E Montserrat E, Lopez-Guillermo A Ott G, Muller-Hermelink HK, Connors JM, Braziel R, Grogan TM, Fisher RI, Miller TP, LeBlanc M, Chiorazzi M, Zhao H, Yang L, Powell J, Wilson WH, Jaffe ES, Simon $R$, Klausner RD, Staudt LM: Molecular diagnosis of primary mediastinal B cell lymphoma identifies a clinically favorable subgroup of diffuse large $B$ cell lymphoma related to Hodgkin lymphoma. J Exp Med 2003, 198:85 I-862.

25. Savage K, Monti S, effery Kutok JL, Cattoretti G, Neuberg D, de LevalL, Kurtin P, Paola Cin PD, Ladd C, Feuerhake F, Aguiar RCT, Li S, Salles $S$, Berger F, Jing W, Pinkus GS, Habermann T, Dalla-Favera R, Harris NL, Aster JC, Golub TR, and Margaret A, Shipp MA: The molecular signature of mediastinal large B-cell lymphoma differs from that of other diffuse large B-cell lymphomas and shares features with classical Hodgkin lymphoma. Blood 2003, | 02:387|-3879.

26. Pileri SA, Zinzani PL, Gaidano G, Falini B, Gaulard P, Zucca E, Sabattin E, Ascani S, Rossi M, Cavalli F, International Extranodal Lymphoma Study Group: Pathobiology of primary mediastinal B-cell lymphoma. Leuk Lymphoma 2003, 44:S2I-S26.

27. Carbone A Gloghini A, Gaidano G, Franceschi S, Capello D, Drexler HG, Falini B, Dalla-Favera R: Expression status of BCL-6 and syndecan-I identifies distinct histogenetic subtypes of Hodgkin's disease. Blood 1998, 92:2220-2228.

28. Torlakovic E, Tierens A, Dang HD, Delabie J: The transcription factor PU.I, necessary for B-cell development, is expressed in lymphocyte predominance, but not classical Hodgkin's disease. Am J Pathol 2001, I59:1807-1814

29. Copie-Bergman C, Plonquet A, Alonso MA, Boulland ML, Marquet J, Divine M, Moller P, Leroy K, Gaulard P: MAL expression in lymphoid cells: further evidence for MAL as a distinct molecular marker of primary mediastinal large B-cell lymphomas. Mod Pathol 2002, I5: I 172-I180.

30. Rowe M, Peng-Pilon M, Huen DS, Hardy R, Croom-Carter D, Lundgren $E$, Rickinson AB: Upregulation of bcl-2 by the Epstein-Barr virus latent membrane protein LMPI: a B-cell-specific response that is delayed relative to NF-kappa $B$ activation and to induction of cell surface markers. J Virol 1994, 68:5602-5612.

31. Yang X, He Z, Xin B, Cao L: LMPI of Epstein-Barr virus suppresses cellular senescence associated with the inhibition of p I 6INK4a expression. Oncogene 2000, 1 9:2002-2013.

32. Izumi KM, Kieff ED: The Epstein-Barr virus oncogene product latent membrane protein I engages the tumor necrosis factor receptor-associated death domain protein to mediate $B$ lymphocyte growth transformation and activate NF- $\kappa B$. PNAS 1997, 94:12592-12597.

33. Kim U, Gunther CS, Roeder RG: Genetic Analyses of NFKB I and OCA-B Function: Defects in B Cells, Serum IgM Level, and Antibody Responses in Nfkb I-/-Oca-b-/- Mice. J Immunol 2000, 1 65:6825-6832. 